\title{
ANALISIS PELANGGARAN PEMBAYARAN UPAH MINIMUM (Studi Putusan No. 401/PID.B/2012/PN.Bwi)
}

\author{
Muhamad Abas \\ Universitas Buana Perjuangan Karawang \\ Email: muhamad.abas@ubpkarawang.ac.id
}

\begin{abstract}
Abstrak
Pengertian tentang upah dalam Undang-Undang Republik Indonesia Nomor 13 Tahun 2003 tentang Ketenagakerjaan adalah hak pekerja/buruh yang diterima dan dinyatakan dalam bentuk uang sebagai imbalan dari pengusaha atau pemberi kerja kepada pekerja/buruh yang ditetapkan dan dibayarkan menurut suatu perjanjian kerja, kesepakatan, atau peraturan perundang undangan, termasuk tunjangan bagi pekerja/buruh dan keluarganya atas suatu pekerjaan dan/atau jasa yang telah atau akan dilakukan. Sedangkan Abdul Khakim mengatakan bahwa upah adalah hak pekerja yang diterima dan dinyatakan dalam bentuk uang sebagai imbalan dari pengusaha atau pemberi kerja kepada pekerja yang ditetapkan dan dibayarkan menurut suatu perjanjian kerja, kesepakatan, atau peraturan perundang-undangan, termasuk tunjangan bagi pekerja dan keluarganya atas suatu pekerjaan dan/atau jasa yang telah atau akan dilakukan. Pengertian upah minimum menurut Permenaker Nomor 7 Tahun 2013 tentang upah minimum Pasal 1 ayat 1 bahwa Upah Minimum adalah upah bulanan terendah yang terdiri atas upah pokok termasuk tunjangan tetap yang ditetapkan oleh gubernur sebagai jaring pengaman. Upah minimum ini berlaku bagi pekerja lajang yang memiliki pengalaman kerja 0-1 tahun, berfungsi sebagai jaring pengaman, ditetapkan melalui Keputusan Gubernur berdasarkan rekomendasi dari Dewan Pengupahan dan berlaku selama 1 tahun berjalan.
\end{abstract}

Kata Kunci: Upah Minimum, Pekerja, Pengusaha

Abstract
Definition of wages in the Law of the Republic of Indonesia Number 13 of 2003 on employment shall
be the right of workers who are received and expressed in the form of money in return of employers
or employers to workers stipulated and paid under an employment agreement, agreement or
legislation, including allowances for workers / laborers and their families for work and / or services
that have been or will be done. While Abdul Khakim said that wages are the right of workers who are
accepted and expressed in the form of money in return of employers or employers to workers who are
designated and paid under an employment agreement, agreement or law, including allowances for
workers and their families to a work and / or services that have been or will be done. Understanding
the minimum wage by Regulation of the minister of labor Number 7 of 2013 concerning the minimum
wage of Article 1 paragraph 1 that the Minimum Wage is the lowest monthly wage consisting of the
basic wage including the fixed allowance set by the governor as the safety net. This minimum wage
applies to single workers with O-1 years of working experience, functioning as a safety net,
established by Governor Decree based on recommendation from Wage Council and valid for 1 year.

Keywords: Minimum Wage, Labourer,

Industrialist 


\section{PENDAHULUAN}

Pembangunan ketenagakerjaan di Indonesia sebagai bagian yang tidak dapat terpisahkan dari pembangunan nasional yaitu upaya yang diselenggarakan oleh semua komponen bangsa dalam rangka mencapai tujuan bernegara. Maka sesuai dengan itu Permenakertrans No. PER. 03 /MEN /I /2010 tentang Rencana Strategis Kemenakertrans 2010-2014 yang dilaksanakan dalam rangka mewujudkan pembangunan manusia Indonesia seutuhnya dan pembangunan masyarakat Indonesia seluruhnya.

Pembangunan ketenagakerjaan mempunyai tujuan yaitu untuk meningkatkan harkat martabat dan harga diri pekerja serta mewujudkan masyarakat yang sejahtera adil makmur dan merata, baik secara materil maupun spiritual, ${ }^{1}$ yang berdasarkan Pancasila dan Undang-Undang Dasar Negara Republik Indonesia Tahun 1945.

Untuk itu diharapkan dengan adanya pembangunan ketenagakerjaan yang mempunyai banyak bidang dan keterkaitan, keterkaitan itu tidak hanya dengan kepentingan pekerja selama, sebelum dan sesudah masa kerja tetapi juga keterkaitan dengan kepentingan pengusaha, pemerintah, dan masyarakat. Maka diperlukan pengaturan yang menyeluruh, antara lain yang mencakup tentang pengembangan sumber daya manusia, dan peningkatan produktivitas serta daya saing pekerja Indonesia, melalui upaya perluasan kesempatan kerja, pelayanan penempatan pekerja, dan pembinaan hubungan industrial.

Pekerja sebagai pelaku perekonomian perlu mendapatkan perlindungan karena kedudukannya yang lemah tunduk kepada perintah pengusaha, perlindungan hukum terhadap pekerja harus sesuai dengan martabat manusia dan moral agama adalah dalam hal keselamatan, kesehatan, kesusilaan, dan pemeliharaan moral kerja sesuai dengan bunyi pasal 27 ayat (2) Undang-Undang Dasar Negara Republik Indonesia Tahun 1945 yaitu bahwa "Tiap-tiap warga negara berhak atas pekerjaan dan

\footnotetext{
${ }^{1)}$ Pustaka Yusticia (ed), Kompilasi Hukum Ketenagakerjaan dan Jamsostek, (Yogyakarta: Pustaka Yusticia, 2010), hal. 63.
} 
penghidupan yang layak bagi pekerja/buruh yang diterima dan kemanusiaan". 2

Pekerja juga perlu mendapatkan perlindungan dalam hal upah atau imbalan sesuai bunyi pasal 28D ayat (2) di Undang-Undang Dasar Negara Republik Indonesia Tahun 1945 yaitu bahwa "Setiap orang berhak untuk bekerja serta mendapat imbalan dan perlakuan yang adil dan layak dalam hubungan kerja". 3

Dengan demikian hak setiap warga negara Indonesia untuk dapat mendapatkan pekerjaan, yang dijamin oleh pemerintah, selain itu juga, upah yang merupakan hasil pekerjaan diharapkan mampu menunjang kebutuhan hidup para pekerja dan keluarganya secara berkesinambungan.

Upah yang diterima pekerja tersebut telah mendapatkan perlindungan dari pemerintah sesuai sesuai UndangUndang Nomor 13 Tahun 2003 tentang Ketenagakerjaan Pasal 1 ayat (30), yang menjelaskan upah adalah hak

2) Undang-Undang Dasar Negara Republik Indonesia Tahun 1945 Amandemen ke 4, Pasal 27 ayat (2).

3) Ibid, Pasal 28D ayat (2). dinyatakan dalam bentuk uang sebagai imbalan dari pengusaha atau pemberi kerja kepada pekerja/buruh yang ditetapkan dan dibayarkan menurut suatu perjanjian kerja, kesepakatan, atau peraturan perundang undangan, termasuk tunjangan bagi pekerja/buruh dan keluarganya atas suatu pekerjaan dan/atau jasa yang telah atau akan dilakukan.

Pada tahun 2010 Dewan Pengupahan Provinsi Jawa Timur melalui Pemerintahan daerah Jawa Timur yaitu Gubernurnya menetapkan upah minimum melalui peraturan Gubernur Jawa Timur Nomor 69 Tahun 2009 tentang Upah Minimum Kabupaten/Kota di Jawa Timur Tahun 2010.

Upah minimum Kabupaten/Kota di Jawa Timur tersebut khusus untuk di Kabupaten Banyuwangi sebesar Rp.824.000,- (delapan ratus dua puluh empat ribu rupiah) per bulan yang harus dibayarkan pengusaha/perusahaan kepada pekerja lajang dengan masa kerja 0 (nol) sampai 1 (satu) tahun.

Dalam pelaksanaan upah minimum, maka Dinas Sosial Tenaga Kerja dan Transmigrasi (selanjutnya 
disebut Disnaker) Banyuwangi PERMASALAHAN

melakukan pengawasan terhadap pelaksanaan upah minimum di perusahaan-perusahaan diwilayah kerjanya. Karena upah adalah hak normatif pekerja maka sesuai peraturan pekerja berhak melaporkan ke Disnaker jika perusahaan ditempat bekerjanya dengan sewenang-wenang melakukan pembayaran upah dibawah upah minimum.

Seperti halnya yang dilakukan oleh pekerja di perusahaan yang bernama PT Maya Muncar dengan alamat Jalan Sampangan No. 22 Muncar Banyuwangi yang melaporkan perusahaan tersebut ke Disnaker Banyuwangi karena telah melakukan pembayaran upah pekerjanya dibawah upah minimum. Maka selanjutnya petugas Disnaker Banyuwangi langsung melakukan pemeriksaan yang kemudian masuk pengajuan perkara di Pengadilan Negeri (selanjutnya disebut PN) Banyuwangi oleh Disnaker Banyuwangi.
Berdasarkan uraian tersebut di atas, maka dapat dirumuskan pokok permasalahan sebagai berikut:

1) Bagaimana penerapan hukum dalam perkara pelanggaran pembayaran upah minimum di Pengadilan Negeri Banyuwangi?

2) Bagaimana kompetensi Pengadilan Negeri Banyuwangi dalam perkara pelanggaran pembayaran upah minimum Kabupaten/Kota?

3) Apakah pertimbangan hakim Pengadilan Negeri Banyuwangi dalam memeriksa dan memutus perkara pelanggaran pembayaran upah minimum di Banyuwangi bertentangan dengan UndangUndang Nomor 13 Tahun 2013 tentang Ketenagakerjaan?

\section{METODE PENELITIAN}

Penelitian ini berdasarkan penelitian kualitatif dengan pendekatan Yuridis Normatif, yaitu penelitian hukum yang dilakukan dengan melakukan studi terhadap bahan kepustakaan, karena metode ini kiranya dapat membahas masalah-masalah yang berkaitan dengan pelanggaran pembayaran upah minimum, yang meliputi: 
1. Spesifikasi Penelitian

Penulisan

penelitian

menggunakan metode deskriptif yaitu memusatkan pada masa sekarang atau pada masalah-masalah aktual lainnya. Dalam pelaksanaannya adalah mengumpulkan data, menyusun data, menjelaskan, menganalisa data dan menginterpretasikan tentang arti dari itu.

2. Pendekatan Penelitian

Menggunakan pendekatan yuridis normatif dengan, yaitu menguji dan mengkaji data sekunder yang berkaitan dengan permasalahan yang akan dibahas.

3. Metode/Teknik Pengumpulan Data

a. Penelitian Perpustakaan:

1) Bahan hukum primer berupa Undang-Undang yang berlaku di Indonesia sebagai bahan hukum yang mengikat.

2) Bahan hukum sekunder yang berasal dari buku-buku pedoman sebagai acuan dalam penelitian ini, dengan mengambil inti yang ada kaitannya dengan bab-bab yang akan ditulis. Metode ini disebut metode literer atau books survey.
3) Bahan hukum tersier yang berasal majalah, internet atau surat kabar dan media pendukung lain yang ada hubungannya dengan masalah yang akan diteliti

b. Penelitian Lapangan:

Melakukan tanya jawab (metode interview) atau Pengamatan /Observasi Penelitian lapangan (field research) dengan mengambil data dari media dan/atau mewancarai Hakim.

4. Pengolahan Data

Karena penelitian ini mempergunakan metode dogmatik hukum, yang cenderung didasarkan pada hukum logika, maka setelah semua data mentah dikumpulkan, dan telah dinyatakan valid dan reliabel, maka langkah selanjutnya adalah pengolahan data yang dilakukan dengan kegiatankegiatan antara lain: Memilih pasal-pasal yang berisikan kaidah-kaidah hukum yang mengatur masalah pengupahan; Membuat sistematik dari pasal-pasal tersebut, sehingga mengahasilkan klasifikasi-klasifikasi tertentu; Menganalisa pasal-pasal tersebut, dengan 
mempergunakan azas-azas hukum yang ada; dan menyusun suatu konstruksi,

5. Analisis Data

Dalam penelitian ini, penulis menggunakan teknis analisis deduksi Metode deduksi adalah metode yang berpangkal dari pengajuan premis mayor yang kemudian diajukan premis minor dan dari kedua premis tersebut kemudian ditarik suatu kesimpulan atau conclusion. Penelitian hukum yang dilakukan oleh penulis adalah dengan menggunakan interpretasi gramatikal. Interpretasi gramatikal merupakan cara penafsiran atau penjelasan untuk mengetahui makna ketentuan undang-undang dengan menguraikannya menurut bahasa, susun kata atau bunyinya. Makna ketentuan undang-undang dijelaskan menurut bahasa sehari-hari yang umum. Hakim tidaklah terikat erat pada bunyi kata-kata dari undang-undang.

\section{PEMBAHASAN}

\section{Penerapan Hukum dalam perkara pelanggaran pembayaran upah minimum.}

Penelitian dilakukan terhadap yurisprudensi, maka yang mula-mula harus dilakukan adalah mengidentifikasi kaidah hukumnya. Biasanya keputusan hakim dari sudut isinya dapat dibagi tiga, yaitu:

1) Pertimbangan-pertimbangan tentang kenyataan-kenyataan yang didapati oleh hakim setelah melakukan perkara itu.

2) Pertimbangan-pertimbangan tentang hukumnya dalam perkara itu yang ditemukan oleh hakim, berdasarkan kenyataan-kenyataan tadi;

3) Keputusannya, atau: dictum. ${ }^{4}$

Dalam hubungan kerja konflik personal antara seorang buruh dengan majikan terkadang disepelekan dan memperlakukannya sebagai konflik yang tidak berkualitas. Pendekatan semacam ini melupakan bahwa setiap konflik bisa berubah dari kekuatan kecil menjadi kekuatan besar. Tidak mudah menghentikan konflik yang digerakkan secara kolektif. Karena itu setiap konflik harus diselesaikan secara adil dan bijak. Cara pandang merupakan hal penting dalam memahami dan menyelesaikan konflik. $^{5}$

\footnotetext{
4) Soerjono Soekanto, Penelitian Hukum Normatif, (Jakarta: Rajawali pers, 2012), hal.68.

${ }^{5}$ Pangaribuan Juanda, Tuntunan Praktis Penyelesaian Perselisihan Hubungan Industrial, (Jakarta: Bumi Intitama Sejahtera, 2010), hal. 2.
} 
a. Kasus Posisi

Pada Tahun 2010 bahwa seorang laki-laki dilaporkan oleh petugas Dinas Tenaga Kerja Kabupaten Banyuwangi diduga karena melakukan tindak pidana yaitu membayar upah pekerja dibawah upah minimum yang telah ditetapkan oleh Gubernur Jawa Timur.

$\begin{array}{rcr}\text { Kasus } & \text { tersebut } & \text { kemudian } \\ \text { ditindaklanjut } & \text { oleh Kepala } & \text { Disnaker } \\ \text { Kabupaten } & \text { Banyuwangi } & \text { untuk }\end{array}$
pemeriksaan lebih lanjut yang kemudian masuk dalam perkara di Pengadilan Negeri Banyuwangi Provinsi Jawa Timur.

b. Amar Putusan

1. Menyatakan terdakwa AGUS WAHYUDIN tersebut telah terbukti secara sah dan meyakinkan bersalah melakukan tindak pidana “ MELAKUKAN PENGUPAHAN TERHADAP BURUHNYA DIBAWAH UMK KABUPATEN BANYUWANGI “;

2. Menjatuhkan pidana kepada terdakwa tersebut diatas, oleh karena itu dengan pidana penjara selama : 1 (satu) tahun, dan membayar denda sebesar Rp. 100.000.000,- (seratus juta rupiah) ;

3. Menyatakan bahwa, apabila pidana denda tersebut tidak dibayar maka diganti dengan pidana kurungan selama 6 (enam) bulan ;

4. Memerintahkan barang bukti berupa:

- Daftar Hadir Karyawan PT. Maya Muncar bulan April 2010 s/d Desember 2010 ;

- Daftar Upah Karyawan bulan April 2010 s/d. Desember 2010 ;

- Bukti Penerimaan Upah (Struk Gaji) ;

- Daftar Karyawan Peserta Jamsostek ;

- SIUP PT Maya Muncar J1 Sampangan No. 22 Muncar Banyuwangi ;

- Wajib Lapor Ketenagakerjaan di Perusahaan a/n. PT.Maya Muncar Banyuwangi Tahun 2009/2010 ;

- Surat Perjanjian Bersama antara SIGIT PRAMUDYO, SH (Personalia PT Maya Muncar) dengan Drs. MF. ROHMAN (Ketua Serikat Pekerja Maya Muncar) ;

- Surat Perjanjian Bersama antara AGUS WAHYUDIN, SIGIT PRAMUDYO, SH, MUCH. FAHIM, SH dengan SUDARMAJI, SOEBEKTI, TIKMIYADI, SUKMAWATI ;

- Putusan Pengadilan Hubungan Industrial antara GEGER SETIYONO (Penggugat) melawan PT. Maya Muncar (Tergugat) terlampir dalam berkas perkara, 
sedangkan Kartu Tanda Penduduk an. AGUS WAHYUDIN dikembalikan kepada Agus Wahyudin dan Kartu Tanda Penduduk an. SIGIT PRAMUDYO, SH dikembalikan kepada Sigit Pramodyo ;

5. Membebankan biaya perkara kepada terdakwa sebesar Rp. 5.000 ( lima ribu rupiah );

\section{Kompetensi Pengadilan Negeri} Banyuwangi Dalam Memutus Perkara Pelanggaran Ketentuan Upah Minimum Kabupaten.

\section{Berdasarkan Pasal 1 Undang-} Undang Nomor 48 Tahun 2009 tentang kekuasaan kehakiman, yang dimaksud dengan kekuasaan kehakiman adalah kekuasaan negara untuk menyelenggarakan peradilan guna menegakkan hukum dan keadilan berdasarkan Pancasila demi terselenggaranya Negara Hukum Republik Indonesia.

Apabila dalam suatu perusahaan terjadi perselisihan tenaga kerja yang merugikan perusahaan maupun tenaga kerja dan tidak dapat diselesaikan melalui jalur non litigasi, maka para pihak dalam hal ini pengusaha maupun pekerja/serikat pekerja dapat membawa perselisihan tersebut melalui jalur litigasi.

Dalam hal pengajuan gugatan akan berkaitan dengan kompetensi. Dalam hukum acara perdata mengenal 2 kompetensi antara lain sebagai berikut :

a) Kompetensi relatif atau wewenang relatif yaitu menyangkut kewenangan mengadili suatu perkara berdasarkan tempat tinggal tergugat dimana diterapkan asas Actor Sequitor Forum Rei. Dalam hal ini berkaitan dengan pengadilan negeri mana yang berwenang untuk mengadili suatu perkara.

b) Kompetensi absolut atau wewenang absolut adalah kekuasaan badan peradilan mana yang berwenang untuk mengadili suatu perkara (Pasal 118 HIR).

Berdasarkan pokok perkara, maka pembayaran upah dibawah upah minimum kota yang dilakukan oleh Agus Wahyudin merupakan suatu pelanggaran akan ketentuan undang-undang ketenagakerjaan yang mengandung unsur melawan hukum. Pasal 89 Undang- 
Undang No. 13 Tahun 2003 tentang

Ketenagakerjaan memberikan penjelasan sebagai berikut:

(1) Upah minimum sebagaimana dimaksud dalam Pasal 88 ayat (3) huruf a terdiri atas:

a. Upah minimum kota berdasarkan wilayah provinsi atau kabupaten/kota;

b. Upah minimum berdasarkan sektor pada wilayah provinsi atau kabupaten/kota;

(2) Upah minimum sebagaimana dimaskud dalam ayat (1) diarahkan kepada pencapaian kebutuhan hidup layak.

(3) Upah minimum sebagaimana dimaksud dalam ayat (1) ditetapkan oleh Gubernur dengan memperhatikan rekomendasi dari Dewan Pengupahan Provinsi dan/atau Bupati/Walikota.

(4) Komponen serta pelaksanaan tahapan pencapaian kebutuhan hidup layak sebagaimana dimaksud dalam ayat (2) diatur dengan Keputusan Menteri.

Di dalam Pasal 90 ayat (1) dijelaskan bahwa " Pengusaha dilarang membayar upah lebih rendah dari upah minimum sebagaimana dimaksud dalam Pasal 89".
Berdasarkan ketentuan dari Pasal 89 dan Pasal 90 ayat (1) Undang-Undang No.13 Tahun 2003 tentang Ketenagakerjaan tersebut, pengusaha berkewajiban memberikan upah kepada pekerja sesuai dengan ketentuan yang telah diatur dalam undang-undang.

Pemberian upah yang sesuai dengan ketentuan perundang-undangan bertujuan agar upah yang diberikan dapat memenuhi kebutuhan hidup yang layak bagi pekerja. Dalam Pasal 90 ayat (2) dijelaskan bahwa bagi pengusaha yang tidak mampu membayar upah minimum sebagaimana dimaksud dalam Pasal 89 dapat dilakukan penangguhan.

Penangguhan pelaksanaan upah minimum diajukan oleh pengusaha kepada Gubernur melalui instansi yang bertanggung jawab di bidang ketenagakerjaan. Penangguhan pelaksanaan upah minimum dimaksudkan untuk membebaskan pengusaha yang bersangkutan melaksanakan upah minimum yang berlaku dalam kurun waktu tertentu.

Apabila penangguhan tersebut telah berakhir, maka pengusaha yang bersangkutan wajib melaksanakan upah 
minimum yang berlaku pada saat itu tetapi tidak wajib membayar pemenuhan ketentuan upah minimum yang berlaku pada waktu diberikan penangguhan.

3. Apakah Pertimbangan Hakim Pengadilan Negeri Banyuwangi Bertentangan Dengan Undang-Undang No.23 Tahun 2003 Tentang Ketenagakerjaan

Pengadilan merupakan tempat untuk mencari keadilan dimana hukum tersebut benar-benar ditegakkan. Setiap perkara yang masuk dalam pengadilan wajib diperiksa oleh hakim. Hakim dalam memeriksa dan memutus suatu perkara diharapkan tidak memihak kepada satu pihak.

Dalam hal penjatuhan putusan oleh Majelis Hakim harus mengandung unsur keadilan, kemanfaatan dan kepastian hukum. Dalam mengambil putusan suatu perkara, Majelis Hakim harus mempertimbangkan hukum, kebiasaan, perjanjian yang ada dan keadilan. ${ }^{6}$

6) Ibid, Hal. 37.
Dengan melihat pertimbangan hukum yang ada, maka putusan Majelis Hakim Pengadilan Negeri Banyuwangi tersebut sudah sesuai dengan nilai keadilan walaupun hukuman yang diputuskan tidak maksimal sesuai yang telah diatur dalam ketentuan Pasal 185 ayat (1) Undang-Undang No.13 Tahun 2003 tentang Ketenagakerjaan, yaitu pidana penjara 4 (empat) tahun penjara dan denda Rp. 400.000.000,- (empat ratus juta rupiah) tapi hanya 1 (satu) tahun penjara dan denda Rp. 100.000.000,(seratus juta rupiah) serta pidana kurungan selama 6 (enam) bulan apabila pidana denda tidak dibayar oleh terdakwa, namun dalam penjatuhan putusan karena merupakan kewenangan hakim untuk menjatuhkan sanksi pidana dan/atau sanksi denda kepada terdakwa paling tidak sudah sesuai dengan tuntutan dari Penuntut Umum.

Penjatuhan denda tersebut berfungsi memberikan efek jera kepada terdakwa agar terdakwa tidak mengulangi perbuatan tersebut dikemudian hari serta memberikan gambaran kepada masyarakat akan adanya keadilan dan kepastian hukum, juga agar pengusaha 
yang lain tidak mengikuti perbuatan terdakwa yang merugikan pekerjanya.

\section{KESIMPULAN DAN SARAN}

\section{Kesimpulan}

a. Tentang penerapan hukum, bahwa Putusan Hakim yang memerintahkan terdakwa menjalani pidana penjara selama 1 (satu) tahun dan dijatuhkannya denda Rp 100.000.000.- (Seratus juta rupiah) adalah hukuman minimal terhadap pasal yang dilanggar sebagaimana ketentuan Pasal 185 ayat (1) Undang-Undang Nomor 13 Tahun 2003 tentang Ketenagakerjaan, dan sesuai dengan nilai keadilan sebagai bentuk pembelajaran (efek jera) untuk tidak dilakukan lagi oleh para pengusaha walaupun dalam penjatuhan putusan merupakan kewenangan hakim untuk menjatuhkan sanksi pidana ataupun sanksi denda kepada terdakwa.

b. Tentang kompetensi Pengadilan, bahwa kasus pelanggaran pembayaran upah dibawah upah minimum kabupaten/kota dapat dikategorikan sebagai tindak pidana dan bukan merupakan yang termasuk dalam perselisihan hak yang mana tindak pidana tersebut merupakan delik yang bersifat kualitatif. Disebut sebagai suatu pelanggaran, sebab ada peraturan perundang-undangan yang mengatur perbuatan tersebut dalam hal ini Pasal 185 ayat (1) Undang-Undang No.13 Tahun 2003. Pelanggaran akan pembayaran upah minimum kabupaten/kota merupakan kompetensi (kewenangan) Pengadilan Negeri bukan merupakan kewenangan Pengadilan Hubungan Industrial. Oleh sebab itu, berkaitan dengan kompetensi absolut atau kewenangan mutlak, maka pelanggaran ketentuan pembayaran upah dibawah upah minimum kabupaten/kota merupakan kewenangan Pengadilan Negeri dalam memeriksa, memutus, dan mengadili perkara tersebut.

c. Tentang pertimbangan hakim, bahwa dalam kasus pelanggaran ketentuan upah minimum, pengusaha melanggar ketentuan yang ada dalam Pasal 90 Jo Pasal 185 Undang-Undang Nomor 13 Tahun 2003 tentang Ketenagakerjaan, Peraturan Menteri Tenaga Kerja Nomor : PER-07/MEN/2013 tentang Upah Minimum yang menggantikan 
Permenaker No. PER-01/MEN/1999 yang

di ubah dengan Kepmenaker. No. 226

Tahun 2000; dan Surat Keputusan Gubernur Jawa Timur Nomor 69 Tahun 2009 tentang Upah Minimum Kabupaten/Kota di Provinsi Jawa Timur Tahun 2010. Pemberian upah minimum dibawah upah minimum kabupaten/kota dikategorikan sebagai pelanggaran dari hukum ketenagakerjaan yang mana pelanggaran tersebut merupakan tindak pidana dan telah memenuhi unsur-unsur yang ada dalam Pasal 90 jo Pasal 185 ayat (1) Undang-Undang No.13 Tahun 2003 tentang Ketenagakerjaan. Hakim dalam menjatuhkan putusan menggunakan interpretasi sistematis atau logis yaitu melakukan penafsiran undangundang sebagai bagian dari keseluruhan sistem perundang-undangan dengan jalan menghubungkan dengan Undang-Undang lain, yang mana Hakim dalam menjatuhkan putusan tidak hanya mengacu pada satu Undang-Undang saja tetapi juga mengacu pada peraturan perundang-undangan lainnya yang berkaitan dengan perkara tersebut. Dalam hal penjatuhan putusan hakim berlaku asas lex specialist derogat legi generali
(Undang-Undang yang khusus mengalahkan Undang-Undang yang umum). Dengan melihat pertimbangan hukum yang ada, maka putusan hakim Pengadilan Negeri Banyuwangi tersebut tidak bertentangan dengan UndangUndang No.13 Tahun 2003 tentang Ketenagakerjaan.

\section{Saran}

a. Bahwa dalam menjatuhkan putusan, putusan hakim tersebut harus mengandung nilai keadilan, kemanfaatan dan kepastian hukum bagi para pihak. Dalam mengambil putusan hakim juga harus mempertimbangkan hukum, perjanjian yang ada, kebiasaan dan keadilan. Hakim semata-mata bukanlah sebagai pelaksana undang-undang saja, tetapi ia juga dapat melakukan penemuan hukum. Dalam melakukan penemuan hukum, ia dapat menganut aliran hukum Freirechtslehre dimana hakim dapat mengisi kekosongan hukum yang ada dengan menggunakan kebiasaan dan perjanjian yang ada dalam masyarakat. Nilai keadilan dan kemanfaatan hendaknya tercermin dari adanya sanksi pidana ataupun denda yang dijatuhkan 
hakim bagi terdakwa agar dengan adanya sanksi yang dijatuhkan memberikan efek jera supaya terdakwa tidak mengulangi perbuatan tersebut. Nilai kepastian hukum dapat tercermin dari tindakan hakim dalam memberikan putusan terhadap terdakwa yang telah melanggar ketentuan perundang-undangan.

b. Untuk menghindari terjadinya kasus yang serupa yaitu pelanggaran terhadap pembayaran upah dibawah upah minimum maka saran untuk para pengusaha atau manajemen perusahaan bahwa ber-usaha (bisnis) adalah untuk mendapatkan keuntungan yang sebanyakbanyaknya dan resikonya adalah mengalami kerugian namun dalam etika bisnis dan hukum agama manapun tidak dibenarkan untuk berbuat curang dengan salah satu caranya yaitu membayar upah pekerja dibawah upah minimum. Pengusaha harus berpikir positif bahwa jika kesejahteraan pekerja meningkat, secara otomatis motivasi kerja juga meningkat yang akan menghasilkan produktivitas yang tinggi dan akhirnya keuntungan pun akan semakin tinggi. Pengusaha jangan berpikir negatif dengan mengganggap pekerja hanya sebagai alat untuk memperkaya diri. Pengusaha harus mentaati peraturan dan norma yang berlaku.

c. Saran untuk Pemerintah yaitu untuk memperbaiki peraturan yang masih menimbulkan dispute/sengketa yang terus berulang terjadi setiap tahunnya yaitu mengenai penetapan upah minimum dan outsourcing, upaya pemerintah juga dapat dengan cara menurunkan harga kebutuhan hidup sehingga dapat menurunkan nilai KHL, apalagi dalam menghadapi pasar bebas maka Pemerintah harus lebih proaktif untuk membuat standarisasi kompetensi pekerja.

d. Saran untuk pekerja dan serikat pekerja yaitu untuk menghadapi pasar bebas tenaga kerja di lima sektor yaitu pariwisata, kesehatan, logistik, informasi, dan perhubungan udara, maka untuk dapat bersaing dan meningkatkan posisi tawar, pekerja Indonesia harus lebih meningkatkan kompetensi keterampilan (skill) dibidangnya masing-masing dan juga keterampilan dasar, yaitu diantaranya Bahasa Inggris, Komputer, Kepemimpinan, Negosiasi, Problem solving/pemecahan masalah dan 
Analisis Pelanggaran Pembayaran Upah Minimum (Studi Putusan No. 401/PID.B/2012/PN.Bwi) :

Muhamad Abas

keterampilan meyakinkan orang agar jangan sampai pekerja kita menjadi tamu di negeri sendiri.

\section{DAFTAR PUSTAKA}

\section{Buku}

Abdul, Khakim. Pengantar Hukum Ketenagakerjaan Indonesia. Bandung: Citra Aditya Bakti, 2009.

Asri, Wijayanti. Hukum Ketenagakerjaan Pasca Reformasi. Jakarta: Sinar Grafika, 2010.

Pangaribuan, Juanda. Tuntunan Praktis Penyelesaian Perselisihan Hubungan Industrial. Jakarta: Bumi Intitama Sejahtera, 2010.

Soerjono, Soekanto. Penelitian Hukum Normatif, Cet. ke-14, Jakarta: Rajawali Pers, 2012.

Surya Tjandra dan Jafar Suryomenggolo, Makin Terang Bagi Kami Belajar Hukum Perburuhan, Jakarta: TURC, 2006.

Tim Redaksi, Kompilasi Hukum Ketenagakerjaan dan Jamsostek, Yogyakarta: Pustaka Yusticia, 2010

\section{Peraturan Perundang-undangan}

Indonesia, Undang-Undang Dasar 1945 perubahan ke IV tahun 2002.

Indonesia, Undang-Undang No. 13 Tahun 2003 tentang Ketenagakerjaan dengan Putusan Mahkamah Konstitusi No. 012/PUU-I/2003 
Tanggal 26 Oktober 2004, Putusan Mahkamah Konstitusi No. 27/PUU-IX/2011 Tanggal 17 Januari 2012, Putusan Mahkamah Konstitusi No. 58/PUU-IX/2011 Tanggal 16 Juli 2012. Putusan Mahkamah Konstitusi No 100/PUU-X/2012 Tanggal 19 September 2013

Indonesia, Undang-Undang No. 21 Tahun 2000 tentang Serikat Pekerja/Serikat Buruh.

Indonesia, Undang-Undang No. 2 Tahun 2004 tentang Penyelesaian Perselisihan Hubungan Industrial.

Indonesia, Undang-Undang Nomor 48 Tahun 2009 tentang Kekuasaan Kehakiman.

Indonesia, Peraturan Pemerintah No. 46 Tahun 2008 tentang Perubahan atas PP No. 8 Tahun 2005 tentang Lembaga Kerja Sama Tripartit.

Indonesia, Peraturan Pemerintah No. 8 Tahun 1981 tentang Perlindungan Upah.

Indonesia, Peraturan Pemerintah No. 38 Tahun 2007 tentang Pembagian urusan Pemerintahan, antara Pemerintah, Pemerintahan Daerah Provinsi dan Pemerintahan Daerah Kabupaten/Kota.

Peraturan Presiden No. 5 Tahun 2010 tentang Rencana Pembangunan
Jangka Menengah Nasional (RPJMN) 2010-2014.

Keputusan Presiden No. 107 Tahun 2004 tentang Dewan Pengupahan.

Instruksi Presiden No. 9 Tahun 2013 tentang Kebijakan Upah Minimum.

Keputusan Menteri Tenaga Kerja dan Transmigrasi Nomor: KEP.231/MEN/2003 tentang Tata Cara Penangguhan Pelaksanaan Upah Minimum

Surat Keputusan Gubernur Jawa Timur Nomor 69 Tahun 2009 tentang Upah Minimum Kabupaten/Kota di Provinsi Jawa Timur.

Putusan Pengadilan Negeri Banyuwangi Nomor 401/Pid.B/2012/PN.Bwi. 